\title{
Leydig cell re-generation and expression of cell signaling molecules in the germ cell-free testis
}

\author{
P J O'Shaughnessy, I D Morris ${ }^{1}$ and P J Baker \\ Division of Cell Sciences, Institute of Comparative Medicine, University of Glasgow Veterinary School, Bearsden \\ Road, Glasgow G61 1QH, UK and ${ }^{1}$ Hull York Medical School, John Hughlings Jackson Building, The University \\ of York, Heslington, York YO10 5DD, UK
}

Correspondence should be addressed to P J O'Shaughnessy; Email: p.j.oshaughnessy@vet.gla.ac.uk

\begin{abstract}
Leydig cells in the rat testis can be specifically ablated with ethane dimethane sulfonate (EDS) and will subsequently re-generate. In this study, we have characterized Leydig cell re-generation and expression of selected cell-signaling molecules in a germ cell-free model of EDS action. This model offers the advantage that re-generation occurs on a stable background without confounding changes from the regressing and repopulating germ cell population. Adult rats were treated with busulfan to remove the germ cell population and Leydig cells were then ablated with EDS. Testicular testosterone levels declined markedly within 24 h of EDS treatment and started to recover after 8 days. After EDS treatment there were marked declines in levels of Leydig cell-specific mRNA transcripts coding for steroidogenic enzymes cytochrome P450 11 1 1 (Cyp11a1), cytochrome P450 17a1 (Cyp17a1), 3ß-hydroxysteroid dehydrogenase type 1 (Hsd3b1), 17 $\beta$-hydroxysteroid dehydrogenase type $3(\mathrm{Hsd} 17 \mathrm{b3})$ and the $\mathrm{LH}$ receptor. Levels of all transcripts recovered within 20 days of EDS treatment apart from $\mathrm{Hsd} 17 \mathrm{b3}$, which remained undetectable up to 20 days. Immunohistochemical localization of CYP11A1 during the phase of early Leydig cell re-generation showed that the Leydig cell precursors are spindle-shaped peritubular cells. Studies on factors which may be involved in Leydig cell re-generation showed there were significant but transient increases in platelet-derived growth factor A (Pdgfa), leukemia inhibitory factor (Lif), and neurofilament heavy polypeptide (Nefh) after EDS, while desert hedgehog (Dhh) levels declined sharply but recovered by 3 days. This study shows that the Leydig cell precursors are peritubular cells and that expression of Pdgfa and Lif is increased at the start of the re-generation process when precursor proliferation is likely to be taking place.

Reproduction (2008) 135 851-858
\end{abstract}

\section{Introduction}

During normal male fetal development the Leydig cells actively secrete androgen to ensure normal masculinization. Androgen secretion then declines before a second generation of Leydig cells establishes the normal adult pattern of secretion during puberty (Klonisch et al. 2004). In the mouse and rat, the two Leydig cell populations appear to represent distinct cell lineages and show clear differences in their regulation and pattern of development. The fetal Leydig cells arise soon after testis differentiation around 14.5 days of intrauterine development (Majdic et al. 1998) while the adult population starts to develop just before puberty, around postnatal day 12 in the rat (Ariyaratne et al. 2000a). In the mouse, a number of factors have been identified which are involved in fetal Leydig cell differentiation. These include desert hedgehog (DHH), platelet-derived growth factor A (PDGFA), and the Arx homeobox (ARX) and, in each case, gene knockout studies have shown that these factors are required for normal fetal Leydig cell development (Kitamura et al. 2002, Yao et al. 2002, Brennan et al. 2003). In contrast, the factors initiating and regulating development of the adult population of cells remain unclear. A recent study has reported the isolation of stem cells from the pre-pubertal testis, which give rise to Leydig cells in vivo following transplantation (Ge et al. 2006). These stem cells express receptors for PDGFA, leukemia inhibitory factor (LIF), and kit ligand (KITL) and proliferate in the presence of these mitogens (Ge et al. 2006). This would appear to suggest a central role for these growth factors, and in particular PDGF, in the development of the adult Leydig cell cohort.

Despite isolation of the Leydig cell stem cells, the identity of the precursor cells that give rise to the adult Leydig cells remains uncertain and controversial. A number of studies have indicated that Leydig cell precursor cells are predominantly peritubular, based on morphological and immunohistochemical evidence (Haider et al. 1995, Russell et al. 1995, Haider \& Sevros 1998, Ariyaratne et al. 2000a, 2000b). A recent study, however, has reported that the progenitor cells are vascular smooth muscle cells and pericytes, based on the apparent neuronal and glial properties of these cells (Davidoff et al. 2004). Before an understanding of adult Leydig cell differentiation and 
development can be achieved, the origin of the cells needs to be established and further studies are needed.

A convenient model for the investigation of adult Leydig cell development is the ethane dimethane sulfonate (EDS)treated rat. In the adult animal, a single injection of EDS leads to rapid ablation of the existing adult Leydig cells followed by Leydig cell repopulation in a manner that appears to recapitulate the normal developmental process (Teerds 1996, Ariyaratne et al. 2003). This model, therefore, offers the possibility for studying Leydig cell differentiation in a relatively stable environment without the other ongoing background developmental processes that occur naturally as the animal grows through puberty. A potential problem of the EDS model, however, is that loss of Leydig cells and, therefore, androgen secretion is rapidly followed by atrophy of the androgen-dependent spermatogenic epithelium, which repopulates as the Leydig cells re-appear (Sharpe et al. 1990). This, of itself, is likely to have a marked effect on sertoli cell activity, which will confound studies on Leydig cell re-generation. In an attempt to circumvent this problem, we have adapted a model of EDS-induced Leydig cell depletion which used germ cell-free animals (Molenaar et al. 1986). Clearly, this will avoid problems of germ cell depletion and re-generation following EDS. In addition, Leydig cell repopulation occurs more rapidly in rats in which the spermatogenic epithelium is absent either experimentally (Molenaar et al. 1986) or developmentally (Edwards et al. 1988a). This shortening of the re-generation process is likely to increase the chances that transient changes in gene expression will be detected. We report here on the characteristics of Leydig cell depletion and re-generation and the expression of cell signaling molecules following EDS treatment in germ cell-depleted testes.

\section{Results}

\section{Effects of busulfan and EDS on testis morphology and androgen levels}

The busulfan regime used in this study caused a decline in testis weight from $1.96 \pm 0.09$ to $0.77 \pm 0.02 \mathrm{~g}$ 6 weeks after the second injection. This was associated with depletion of germ cells so that tubules were largely devoid of germ cells at the start of EDS treatment (Fig. 1A and $\mathrm{B}$ ). The intratubular nuclei remaining after busulfan treatment had the characteristics of Sertoli cell nuclei (Fig. 1B). The Leydig cells appeared densely packed in the interstitium after germ cell depletion because of tubular shrinkage (Fig. 1A and B).

Treatment with EDS caused a further decline in testis weight over the next 8 days followed by a recovery up to 20 days (Fig. 2A). Testosterone levels dropped markedly over the first $24 \mathrm{~h}$ following EDS and reached a nadir at $3-5$ days before starting to recover at 8 days. By 20 days the levels of testosterone were about $25 \%$ of controls (Fig. 2B). Leydig cell numbers were depleted $24 \mathrm{~h}$ after EDS, and by 3 days post-treatment were almost completely ablated with only a very occasional, morphologically distinct, Leydig cell apparent in the interstitial space (Fig. 1C).

\section{Immunohistochemical expression of CYP11A1}

In untreated rats and in busulfan-treated rats prior to EDS, there was strong expression of cytochrome P450 11a1 (CYP11A1, a marker of steroidogenic cells) in the interstitial Leydig cells. This staining was no longer present by 3 days after EDS (Fig. 1A-C). By 8 days after EDS treatment staining for CYP11A1 had started to re-appear in some peritubular cells and remained exclusively associated with the peritubular cells up to 20 days (Fig. 1D-F). At 8 days there were no CYP11A1positive cells developing next to blood vessels, which were not also lying in a peritubular position. At day 20 the immunostained cells mainly formed clumps closely opposed to the external surface of the tubule although some cells appeared within the interstitial space (Fig. 1F).

\section{Testicular mRNA expression levels following EDS}

Leydig cell-specific genes

Levels of mRNA encoding the three steroidogenic enzymes CYP11A1, cytochrome P450 17a1 (CYP17A1) and $3 \beta$-hydroxysteroid dehydrogenase type 1 (HSD3B1), and the luteinizing hormone receptor (LHR) showed an expression profile after EDS which closely resembled changes in intratesticular testosterone (Fig. 3). There was a rapid fall in expression $24 \mathrm{~h}$ after treatment reaching a nadir around 3-5 days with recovery starting on day 8 . The notable difference to testosterone levels is that expression of these genes returned to normal by 20 days whereas testosterone was still reduced by $75 \%$ at 20 days. The other major steroidogenic enzyme specific to the Leydig cells is $17 \beta$-hydroxysteroid dehydrogenase (HSD17B3), and levels of Hsd17b3 mRNA declined rapidly after EDS to become undetectable by 3 days. Unlike the other steroidogenic enzymes, however, levels of $\mathrm{Hsd} 17 \mathrm{~b} 3$ showed no recovery of expression up to day 20. The levels of Pdgfra mRNA declined about $75 \%$ after EDS and remained low up to 20 days.

\section{Cell-signaling molecules}

Within $24 \mathrm{~h}$ of EDS treatment there was a marked, sixfold increase in Pdgfa mRNA transcript levels (Fig. 4). This change in expression was transient and levels returned to normal by 3 days. There was a similar, though smaller, increase in levels of Lif after EDS. In contrast, levels of Dhh mRNA transcripts declined by about $80 \%$ within the first $24 \mathrm{~h}$ of EDS treatment then returned to normal by 3 days, while insulin-like growth factor I (Igf1) levels declined to $30 \%$ of normal at $24 \mathrm{~h}$ and remained low up to 5 days. Other signaling molecules measured 

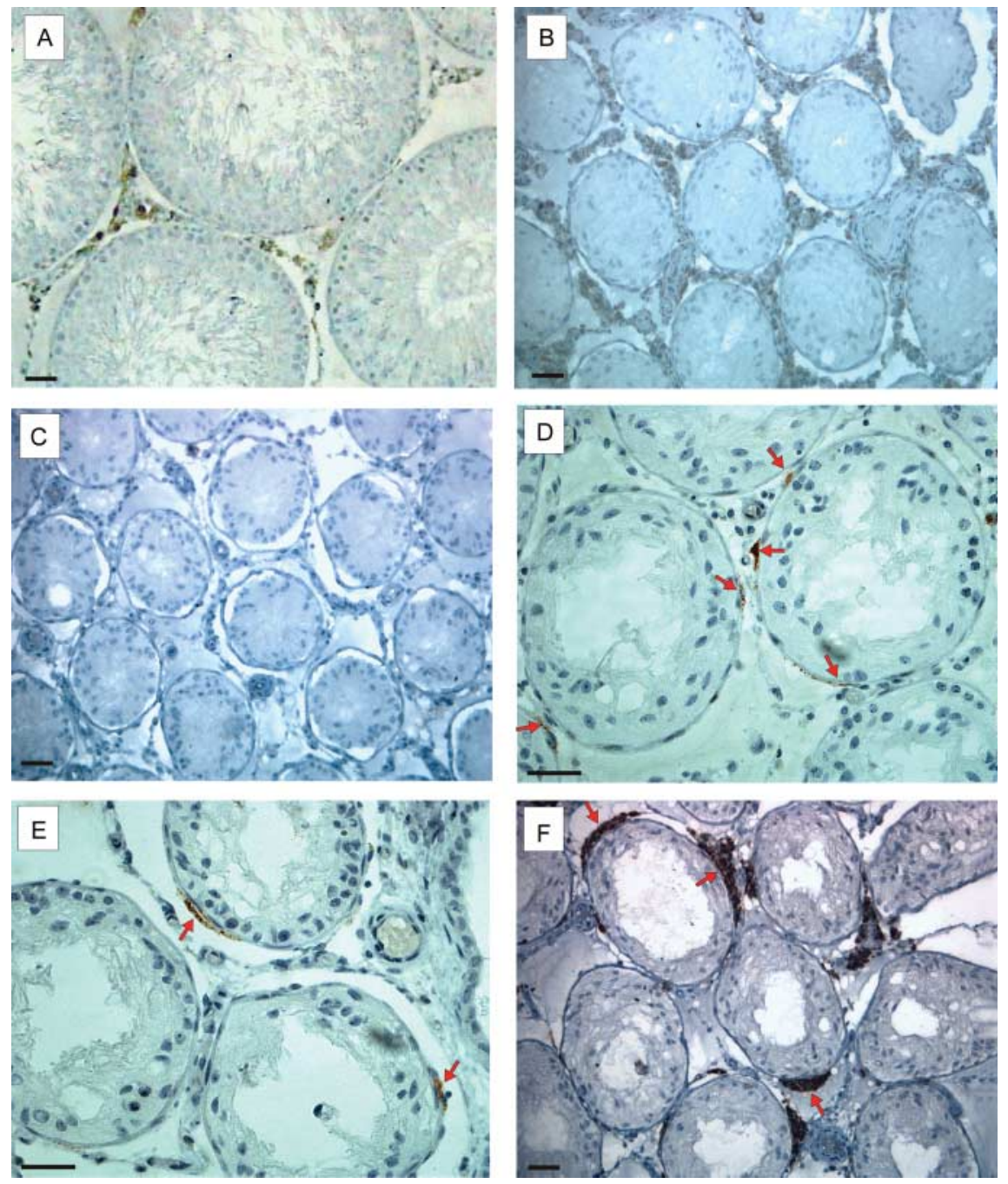

Figure 1 Immunohistochemical localization of CYP11A1 in the testis of untreated rats and rats treated with busulfan to destroy germ cells followed, 10 weeks later, by treatment with EDS. Testis sections $(5 \mu \mathrm{m})$ were incubated with antibody to CYP11A1 and visualized following binding to a biotinylated secondary antibody. In untreated animals (A) and animals treated only with busulfan (B) there was clear and abundant staining in the interstitial tissue. By 3 days after EDS (C) there was no staining for CYP11A1 but after 8 (D) and 12 (E) days clear staining was seen in peritubular cells (red arrows). By 20 days after EDS (F) groups of peritubular cells were stained (red arrows) and some of these cells were spreading into an interstitial localization. This figure also shows that the busulfan treatment regime significantly depleted the germ cell population (e.g., compare A and B). The bar in each picture represents $30 \mu \mathrm{m}$.

(Kitl and wingless-related MMTV integration site 5A (Wnt5a)) showed no significant change in mRNA levels following EDS treatment.

\section{Other genes}

Levels of nuclear receptor subfamily $5 \mathrm{a} 1$ (Nr5a1, also known as Sf1) transcripts declined by about $50 \%$ immediately after EDS treatment but did not differ from control thereafter until 20 days when transcript levels were significantly increased (Fig. 5). Similarly, the levels of Arx transcripts declined immediately after EDS but were not significantly different to control thereafter (Fig. 5). Levels of neurofilament heavy polypeptide (Nefh) increased significantly $24 \mathrm{~h}$ after EDS treatment and then returned to normal whilst there was no significant change in levels of nestin (Nes) transcripts.

\section{Discussion}

In the normal rat, the adult Leydig cell population begins to develop around day 12 after birth and reaches adult numbers by about day 40 (Ariyaratne \& Chamindrani Mendis-Handagama 2000, Ariyaratne et al. 2000a). The underlying mechanism that initiates this process is unknown but recent studies have shown that the testicular interstitium of neonatal rats contains stem cells that can differentiate into steroidogenic cells in vitro or follow transplantation in vivo (Ge et al. 2006). Current 

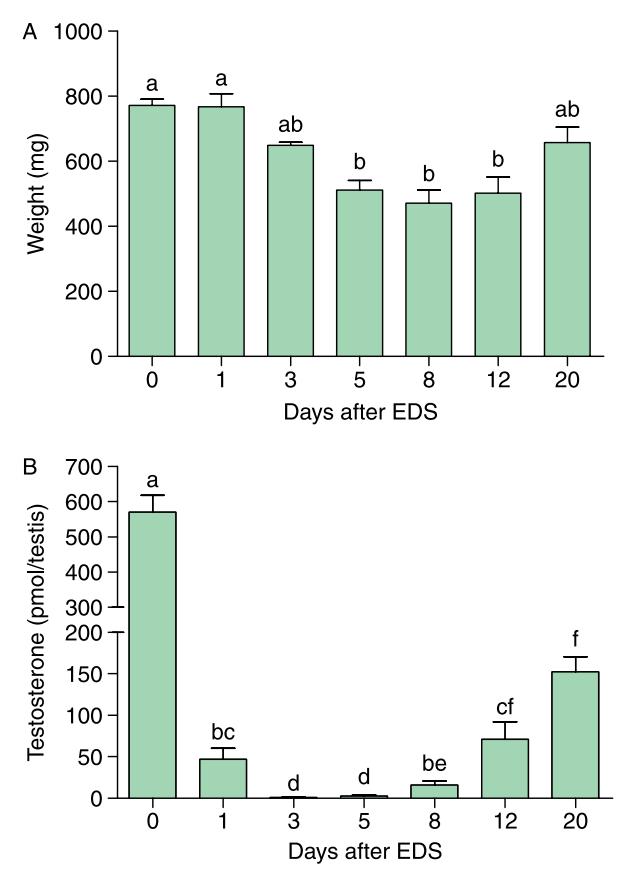

Figure 2 Testis weight (A) and total intratesticular testosterone (B) in rats treated with busulfan to destroy germ cells followed, 10 weeks later, by treatment with EDS. Data show changes in testicular weight and testosterone up to 20 days after EDS. Groups with different letter superscript are significantly different $(P<0.05)$.

evidence suggests that Leydig cell re-population of the adult testis following EDS treatment is very similar to the normal developmental process (Teerds 1996, Ariyaratne et al. 2003) and it is likely that the same stem cells act as precursors of re-populating Leydig cells. The EDS model offers, therefore, a convenient method for the study of Leydig cell development while use of germ cell-free animals, as described here, allows this to be done on a relatively stable background with no other on-going, age-related, developmental events and without the massive degeneration and re-population of the germ cells which normally occurs following EDS.

Following EDS treatment, changes in the levels of mRNA species known to be specific to the Leydig cells followed, in the most part, changes in testosterone levels. The clear exception was Hsd17b3 mRNA which declined at the same rate as other steroidogenic enzymes but did not show any recovery and remained un-detectable up to 20 days. Failure of $\mathrm{Hsd}_{17 \mathrm{~b} 3}$ expression to recover at the same rate as other enzymes may explain why testosterone levels remained relatively low at day 20. In an earlier study we showed that 17-ketoreductase activity (enzyme activity catalyzed by HSD17B3) declined more slowly after EDS than other steroidogenic enzyme activities and remained detectable at all times (O'Shaughnessy \& Murphy 1991). This apparent discrepancy is probably due to the presence of other members of the $17 \beta$-hydroxysteroid dehydrogenase family in the testis (Sha et al. 1996).
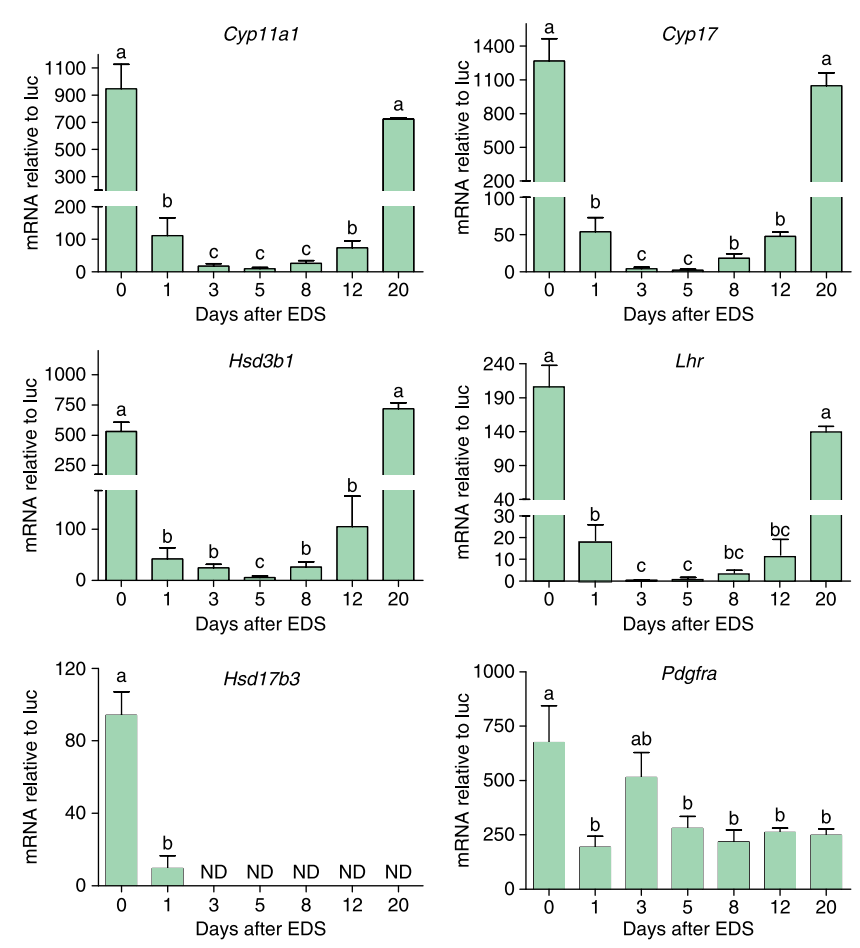

Figure 3 Testicular levels of mRNA species encoding Leydig cellspecific genes in rats treated with busulfan to destroy germ cells followed, 10 weeks later, by treatment with EDS. Data show changes in testicular transcript levels up to 20 days after EDS. Levels of mRNA were measured by real-time PCR and bars represent the mean \pm S.E.M. of data from between three and five animals. Groups with different letter superscript are significantly different $(P<0.05)$.

In the first study of EDS action on the germ cell-free testis it was reported that Leydig cell repopulation after EDS was faster than in normal rats (Molenaar et al. 1986). This is confirmed by our current study which shows that levels of testosterone and most Leydig cell mRNA markers began to recover by 8 days after EDS treatment. This contrasts with normal rats in which testosterone levels begin to recover between 14 and 21 days after EDS (Molenaar et al. 1986, Edwards et al. 1988b, Sharpe et al. 1990, Ariyaratne et al. 2003). It is known that germ cell depletion affects Sertoli cell function (McKinnell \& Sharpe 1997, Guitton et al. 2000, O'Shaughnessy et al. 2008) and so the accelerated re-generation of active Leydig cells in germ cell-depleted testes may be due to altered Sertoli cell activity. Alternatively, LH is required for re-generation of Leydig cells after EDS treatment (Molenaar et al. 1986, Teerds et al. 1989) and levels of LH are higher in germ cell-free animals treated with EDS compared with normal EDStreated animals (Morris \& Jackson 1978, Molenaar et al. 1986). The more rapid Leydig cell re-generation in germ cell-free animals may, therefore, reflect increased tropic stimulation of the developing precursor cells.

Previous studies of adult Leydig cell differentiation, either during normal development or following EDS 

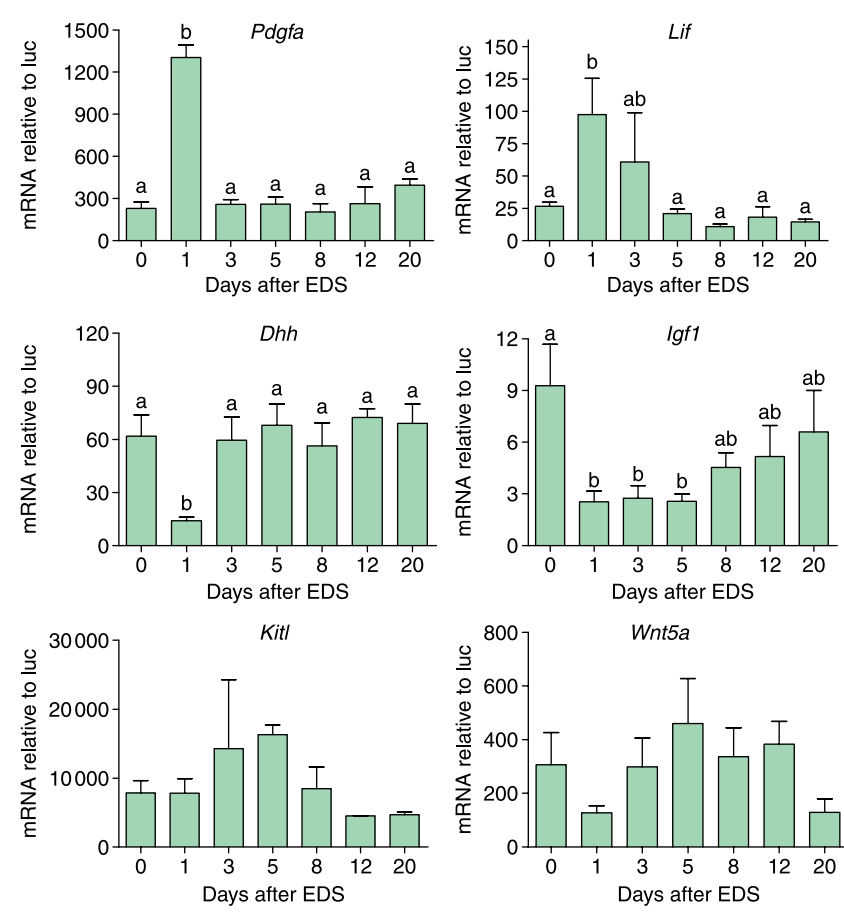

Figure 4 Testicular levels of mRNA species encoding cell-signaling molecules in rats treated with busulfan to destroy germ cells followed, 10 weeks later, by treatment with EDS. Data show changes in testicular transcript levels up to 20 days after EDS. Levels of mRNA were measured by real-time PCR and bars represent the mean \pm s.E.M. of data from between three and five animals. Groups with different letter superscript are significantly different $(P<0.05)$. If no superscripts are shown there was no difference between groups.

in the adult, have identified peritubular, spindleshaped/mesenchymal cells as the immediate precursor cells (Haider et al. 1995, Russell et al. 1995, Ariyaratne et al. 2000a, 2000b). In addition, spindle-shaped peritubular cells have been described recently as Leydig cell stem cells (Ge et al. 2006). In contrast, it has recently been proposed that adult Leydig cells differentiate from perivascular smooth muscle cells and pericytes (Davidoff et al. 2004). This is based on the hypothesis that Leydig cells show neural characteristics and that cells expressing Nes, which is a stem cell marker in the nervous system, appear to differentiate from the perivascular region of the testis after EDS and may then go on to form adult Leydig cells (Davidoff et al. 2004). In addition, expression of Nefh, an intermediate filament protein expressed in the neuronal/glial lineage subsequent to Nes, also increases transiently in perivascular cells. Our studies agree that there is an increase in testicular Nefh expression following EDS although no significant change in Nes was seen. More crucially, however, we saw no evidence of perivascular development of Leydig cells. All cells expressing CYP11A1 during the initial phases of differentiation (around 8 days) were peritubular. From this evidence we cannot rule out a perivascular origin for Leydig cells, and there are other studies suggesting a minor contribution from this source
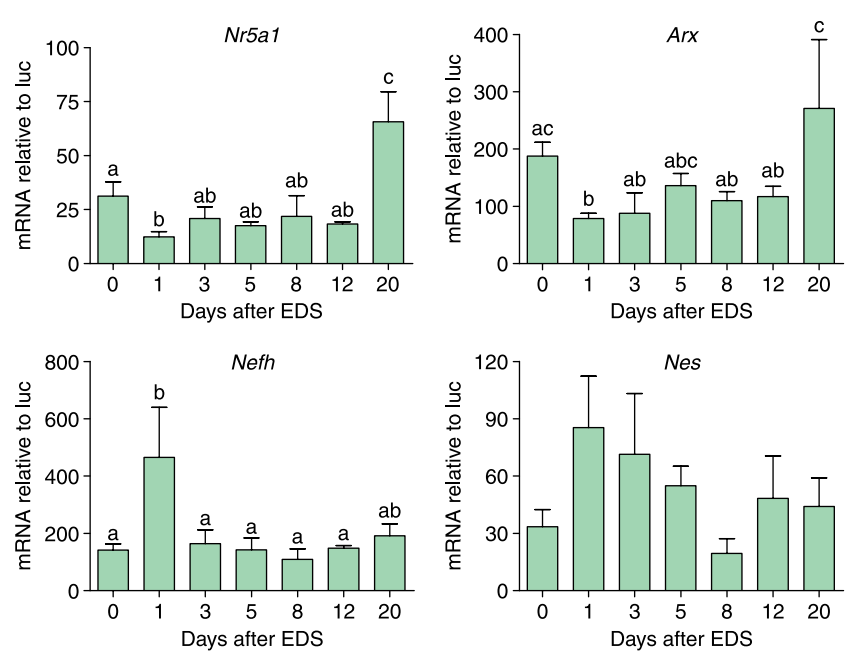

Figure 5 Testicular levels Nr5a1, Arx, Nefh and Nes mRNA in rats treated with busulfan to destroy germ cells followed, 10 weeks later, by treatment with EDS. Data show changes in testicular transcript levels up to 20 days after EDS. Levels of mRNA were measured by real-time PCR and bars represent the mean \pm S.E.M. of data from between three and five animals. Groups with different letter superscript are significantly different $(P<0.05)$. If no superscripts are shown there was no difference between groups.

(Haider et al. 1995, Haider \& Servos 1998), but it is unlikely to be the major site of Leydig cell precursor differentiation.

PDGF is a major mitogen for mesenchymal cells and there is a growing body of evidence that links PDGF signaling with Leydig cell differentiation and development. In Pdgfa-null mice, for example, adult Leydig cells fail to develop, possibly because of a failure of precursor proliferation (Gnessi et al. 2000). Consistent with this hypothesis, the putative Leydig cell stem cells express Pdgfra and PDGFA stimulates stem cell proliferation (Ge et al. 2006). The early, transient rise in Pdgfa mRNA levels after EDS treatment is, therefore, of considerable interest and would be consistent with a role for PDGFA in Leydig cell precursor proliferation and differentiation. In addition to PDGFA, the myoid cell factor LIF also stimulates Leydig cell stem cell proliferation (Ge et al. 2006). Levels of Lif mRNA increased in the testis $24 \mathrm{~h}$ after EDS treatment and then returned to basal levels within 3-5 days. In embryonic stem cells LIF withdrawal is a stimulus for differentiation (Ward et al. 2004) and it is possible that the transient change in levels of Lif after EDS acts both to enhance stem cell proliferation and then to permit Leydig cell differentiation.

$\mathrm{DHH}$ is a cell signaling molecule produced by the sertoli cells and essential for normal differentiation of the fetal and adult Leydig cell populations (Clark et al. 2000, Yao et al. 2002). In DHH-null mice, there is failure of adult Leydig cell differentiation although this may be through failure of precursor proliferation or development (Clark et al. 2000). Following EDS treatment levels of mRNA encoding, DHH declined transiently but 
significantly at $24 \mathrm{~h}$. It is not clear whether this may be related to subsequent Leydig cell re-generation or is simply a response to declining testosterone levels. Levels of Igf1 mRNA also declined after EDS although, unlike $D h h$, levels remained significantly reduced up to 8 days. The pattern of Igf1 expression after EDS is consistent with partial expression in the Leydig cells as reported previously (Moore et al. 1993).

This study characterizes a model system with which to study Leydig cell degeneration and re-generation without marked changes in the germ cell population. Leydig cell re-generation is also more rapid in this system, which may make it simpler to identify changes in gene expression associated with these changes. Our results also provide further support for a peritubular origin of adult Leydig cells and suggest that increasing levels of PDGFA and LIF following Leydig cell ablation may contribute to precursor proliferation.

\section{Materials and Methods}

\section{Animal treatments}

Adult Sprague-Dawley rats (350-400 g) were purchased from Harlan UK (Bicester, Oxfordshire, UK). To remove the germ cell population in these animals they were treated with the cytotoxic drug busulfan that selectively ablates spermatagonia
(Jackson et al. 1962). Rats are sensitive to the toxic effects of busulfan, and initial studies were designed to identify a treatment regime that was effective in ablating the germ cell population without clear systemic toxicity. The most effective regime identified was a modification of one described earlier (Jiang 1998) and required two injections (i.p.) of busulfan $(10 \mathrm{mg} / \mathrm{kg})$ spaced 4 weeks apart. Under this regime, daily observations of the animals indicated that there was no gross toxicity. Six weeks after the second injection of busulfan the animals were injected (i.p.) with EDS $(100 \mathrm{mg} / \mathrm{kg})$ or vehicle. Animals were killed by $\mathrm{CO}_{2}$ inhalation at different times after EDS treatment. One testis was processed immediately for RNA extraction while the other was weighed, cut into two halves and one half fixed in Bouin's medium while the other half was frozen rapidly in liquid $\mathrm{N}_{2}$ and stored at $-20^{\circ} \mathrm{C}$.

\section{Gene expression studies}

Total RNA was extracted from one testis of each animal by homogenization in TRizol (Invitrogen Ltd). At the start of the extraction process, luciferase mRNA (5 ng) was added to each sample to act as an external standard for real-time PCR (Baker \& O'Shaughnessy 2001). Extracted RNA was reverse transcribed using random hexamers and Moloney murine leukemia virus reverse transcriptase (Superscript II, Invitrogen Ltd) as described previously (O'Shaughnessy \& Murphy 1993, O'Shaughnessy et al. 1994). Levels of mRNA were measured

Table 1 Primers used for real-time PCR.

\begin{tabular}{|c|c|c|}
\hline Gene & Abbreviation & Primers \\
\hline Cytochrome P450 side chain cleavage & Cyp11a1 & $\begin{array}{l}\text { GCAGCGACTCTCTTCTCCTGCG } \\
\text { GCCATCACCTCTTGGTTTAGGACAATT }\end{array}$ \\
\hline $3 \beta$-hydroxysteroid dehydrogenase ${ }^{a}$ & $H s d 3 b 1$ & $\begin{array}{l}\text { GACAGGAGCAGGAGGGTTTGTGG } \\
\text { CTCCTTCTAACATTGTCACCTTGGCCT }\end{array}$ \\
\hline Luteinising hormone receptor & Lhr & $\begin{array}{l}\text { CTGCGCCTTCAGGAATTTGCC } \\
\text { AATCATAATCCCAGCСАCTGAGTTCATTCT }\end{array}$ \\
\hline Cytochrome P450 17 $\alpha$-hydroxylase & Cyp17a1 & $\begin{array}{l}\text { TGGTCCCATCTATTCTCTTCGCCTG } \\
\text { AAGGCCACGCCTTTCCCTTG }\end{array}$ \\
\hline $17 \beta$-hydroxysteroid dehydrogenase type 3 & $H s d 17 b 3$ & $\begin{array}{l}\text { AGTGTGTGAGGTTCTCCCGGTACCT } \\
\text { TACAACATTGAGTCCATGTCTGGCCAG }\end{array}$ \\
\hline Desert hedgehog & $D h h$ & $\begin{array}{l}\text { CGTCСССААСТАСАACСССG } \\
\text { CGTCССААССТTСАGTСАСGC }\end{array}$ \\
\hline Wingless-related MMTV integration site 5A & Wnt5a & $\begin{array}{l}\text { CGCGAAGACGGGCATCAAAG } \\
\text { TGGCATTTACCACTCCAGCAGC }\end{array}$ \\
\hline Platelet-derived growth factor $\alpha$ & Pdgfa & $\begin{array}{l}\text { AGGTGAAGCGCTGCACTGGC } \\
\text { TGCGCACTCCAGGTGCTCCT }\end{array}$ \\
\hline Pdgf-receptor $\alpha$ & Pdgfra & $\begin{array}{l}\text { GATAGCTTCATGAGCCGACACCCA } \\
\text { CATTGGCACGTACTGTGTGGTGTCA }\end{array}$ \\
\hline Kit ligand & Kitl & $\begin{array}{l}\text { CCGGGATGGATTGTTTTGCCTAGTC } \\
\text { CACGAGGTCATCCACTATTTTCCCAA }\end{array}$ \\
\hline Insulin-like growth factor 1 & $\lg f 1$ & $\begin{array}{l}\text { TGACCTGCTGTGTAAACGACCCG } \\
\text { CAGCTCAGCCСCGCAAAGG }\end{array}$ \\
\hline Leukemia inhibitory factor & Lif & $\begin{array}{l}\text { GCCATACGCCACCCGTGTCA } \\
\text { TCCGTCATGTTTGGCGCACA }\end{array}$ \\
\hline Neurofilament heavy polypeptide & Nefh & $\begin{array}{l}\text { TCGAAGGACACACGGTGCAGAGTA } \\
\text { CCAACTCTGTGGTCCTGGCCTG }\end{array}$ \\
\hline Nestin & Nes & $\begin{array}{l}\text { AGAAGCGCTGGAACAGAGATTGGA } \\
\text { TCTTGAGG TGTGCCAGTTGCTGC }\end{array}$ \\
\hline Arx homeobox & $\operatorname{Arx}$ & $\begin{array}{l}\text { GTTACCGCACCACGTTCACCAGTTA } \\
\text { CCACTTGGCCCTGCGGTTCT }\end{array}$ \\
\hline Nuclear receptor $5 \mathrm{a} 1$ & Nr5a1 & $\begin{array}{l}\text { CAGGATGGCGGACCAGACCTTTAT } \\
\text { CCTTGCCGTACTGGACCTGGC }\end{array}$ \\
\hline
\end{tabular}

${ }^{\mathrm{a}}$ Amplifies both type 1 and type 2 isoforms. 
by real-time PCR using the SYBR green method with a Stratagene MX3000 cycler. Reactions contained $5 \mu \mathrm{l} 2 \times$ SYBR mastermix (Stratagene, Amsterdam), primers (100 nM), and template in a total volume of $10 \mu \mathrm{l}$. The thermal profile used for amplification was $95^{\circ} \mathrm{C}$ for $8 \mathrm{~min}$ followed by 40 cycles of $95{ }^{\circ} \mathrm{C}$ for $25 \mathrm{~s}, 63{ }^{\circ} \mathrm{C}$ for $25 \mathrm{~s}$, and $72{ }^{\circ} \mathrm{C}$ for $30 \mathrm{~s}$. At the end of the amplification phase a melting curve analysis was carried out on the products formed. All primers were designed by Primer Express 2.0 (Applied Biosystems, Warrington, UK) using parameters previously described (Czechowski et al. 2004). The primers used are described in Table 1.

\section{Immunohistochemistry}

Testes were fixed overnight in Bouin's medium and stored in $70 \%$ ethanol. Wax sections $(5 \mu \mathrm{m})$ were incubated with primary antibody overnight at $4{ }^{\circ} \mathrm{C}$ and endogenous biotin was blocked using an avidin/biotin blocking kit (R\&D systems Europe Ltd, Abingden, UK). The antibody used was rabbit antibovine CYP11A1 (gift from A H Payne). Sections were washed and incubated for 30 min with biotinylated secondary antibody (R\&D Systems Europe Ltd, Abingden, UK). Bound anti-body was visualized using 3,3-diaminobenzidine tetrahydrochloride (R\&D Systems Europe Ltd). Negative controls without the primary antibody were included in each experiment.

\section{RIA}

To measure total intratesticular testosterone, steroids were extracted from the testes with ethanol and measured by RIA as previously described (Sheffield \& O'Shaughnessy 1989).

\section{Statistical analysis}

Data were analyzed by single-factor ANOVA followed by Fisher's multiple comparison test (Minitab, Minitab Ltd, Coventry, UK). Where necessary, data were log-transformed before analysis to avoid heterogeneity of variance.

\section{Acknowledgements}

We thank Dr A H Payne for antibody to CYP11A1. This study was supported by funding from the BBSRC. The authors declare that there is no conflict of interest that would prejudice the impartiality of this scientific work.

\section{References}

Ariyaratne HB \& Chamindrani Mendis-Handagama S 2000 Changes in the testis interstitium of Sprague-Dawley rats from birth to sexual maturity. Biology of Reproduction 62 680-690.

Ariyaratne HB, Mendis-Handagama SM, Hales DB \& Mason JI 2000a Studies of the onset of Leydig precursor cell differentiation in the prepubertal rat testis. Biology of Reproduction 63 165-171.

Ariyaratne HB, Mills N, Mason JI \& Mendis-Handagama SM $2000 \mathrm{~b}$ Effects of thyroid hormone on Leydig cell regeneration in the adult rat following ethane dimethane sulphonate treatment. Biology of Reproduction 63 1115-1123.
Ariyaratne S, Kim I, Mills N, Mason I \& Mendis-Handagama C 2003 Effects of ethane dimethane sulfonate on the functional structure of the adult rat testis. Archives of Andrology 49 313-326.

Baker PJ \& O'Shaughnessy PJ 2001 Expression of prostaglandin D synthetase during development in the mouse testis. Reproduction 122 553-559.

Brennan J, Tilmann C \& Capel B 2003 Pdgfr-alpha mediates testis cord organization and fetal Leydig cell development in the XY gonad. Genes and Development 17 800-810.

Clark AM, Garland KK \& Russell LD 2000 Desert hedgehog (Dhh) gene is required in the mouse testis for formation of adult-type Leydig cells and normal development of peritubular cells and seminiferous tubules. Biology of Reproduction 63 1825-1838.

Czechowski T, Bari RP, Stitt M, Scheible WR \& Udvardi MK 2004 Real-time RT-PCR profiling of over 1400 Arabidopsis transcription factors: unprecedented sensitivity reveals novel root- and shoot-specific genes. Plant Journal 38 366-379.

Davidoff MS, Middendorff R, Enikolopov G, Riethmacher D, Holstein AF \& Muller D 2004 Progenitor cells of the testosterone-producing Leydig cells revealed. Journal of Cell Biology 167 935-944.

Edwards G, Lendon RG \& Morris ID 1988a Accelerated recovery of Leydig cells of the immature rat testis after administration of the cytotoxic ethylene dimethanesulphonate. Journal of Endocrinology 119 475-482.

Edwards G, Robertson WR \& Morris ID 1988b Characterization of the regenerated Leydig cell population of the rat after destruction by ethylene-1,2-dimethanesulphonate. Journal of Endocrinology 117 11-18.

Ge RS, Dong Q, Sottas CM, Papadopoulos V, Zirkin BR \& Hardy MP 2006 In search of rat stem Leydig cells: identification, isolation, and lineagespecific development. PNAS 103 2719-2724.

Gnessi L, Basciani S, Mariani S, Arizzi M, Spera G, Wang C, Bondjers C, Karlsson L \& Betsholtz C 2000 Leydig cell loss and spermatogenic arrest in platelet-derived growth factor (PDGF)-A-deficient mice. Journal of Cell Biology 149 1019-1026.

Guitton N, Touzalin AM, Sharpe RM, Cheng CY, Pinon-Lataillade G, Meritte H, Chenal C \& Jegou B 2000 Regulatory influence of germ cells on sertoli cell function in the pre-pubertal rat after acute irradiation of the testis. International Journal of Andrology 23 332-339.

Haider SG \& Servos G 1998 Ultracytochemistry of 3beta-hydroxysteroid dehydrogenase in Leydig cell precursors and vascular endothelial cells of the postnatal rat testis. Anatomy and Embryology 198 101-110.

Haider SG, Laue D, Schwochau G \& Hilscher B 1995 Morphological studies on the origin of adult-type Leydig cells in rat testis. Italian Journal of Anatomy and Embryology 100 535-541.

Jackson JA, Partington M \& Fox BW 1962 Effect of busulphan (Myleran) on the spermatogenic cell population of the rat testis. Nature 194 1184-1185.

Jiang FX 1998 Behaviour of spermatogonia following recovery from busulfan treatment in the rat. Anatomy and Embryology 198 53-61.

Kitamura K, Yanazawa M, Sugiyama N, Miura H, lizuka-Kogo A, Kusaka M, Omichi K, Suzuki R, Kato-Fukui Y, Kamiirisa K et al. 2002 Mutation of ARX causes abnormal development of forebrain and testes in mice and $\mathrm{X}$-linked lissencephaly with abnormal genitalia in humans. Nature Genetics 32 359-369.

Klonisch T, Fowler PA \& Hombach-Klonisch S 2004 Molecular and genetic regulation of testis descent and external genitalia development. Developmental Biology 270 1-18.

Majdic G, Saunders PK \& Teerds KJ 1998 Immunoexpression of the steroidogenic enzymes 3-beta hydroxysteroid dehydrogenase and 17 alpha-hydroxylase, $\mathrm{C} 17,20$ lyase and the receptor for luteinizing hormone $(\mathrm{LH})$ in the fetal rat testis suggests that the onset of Leydig cell steroid production is independent of $\mathrm{LH}$ action. Biology of Reproduction 58 520-525.

McKinnell C \& Sharpe RM 1997 Regulation of the secretion and synthesis of rat Sertoli cell SGP-1, SGP-2 and CP-2 by elongate spermatids. International Journal of Andrology 20 171-179.

Molenaar R, de Rooij DG, Rommerts FFG \& van der Molen HJ 1986 Repopulation of Leydig cells in mature rats after selective destruction of the existent Leydig cells with ethylene dimethane sulfonate is dependent on luteinizing hormone and not follicle-stimulating hormone. Endocrinology 118 2546-2554. 
Moore A, Chen CL, Davis JR \& Morris ID 1993 Insulin-like growth factor-I mRNA expression in the interstitial cells of the rat testis. Journal of Molecular Endocrinology 11 319-324.

Morris ID \& Jackson CM 1978 Gondadotrophin response after castration and selective destruction of the testicular interstitium in the normal and aspermatogenic rat. Acta Endocrinologica 88 38-47.

O'Shaughnessy PJ \& Murphy L 1991 Steroidogenic enzyme-activity in the rat testis following leydig-cell destruction by ethylene-1,2-dimethanesulfonate and during subsequent leydig-cell regeneration. Journal of Endocrinology 131 451-457.

O'Shaughnessy PJ \& Murphy L 1993 Cytochrome P-450 17 $\alpha$-hydroxylase protein and mRNA in the testis of the testicular feminized (Tfm) mouse. Journal of Molecular Endocrinology 11 77-82.

O'Shaughnessy PJ, Marsh P \& Dudley K 1994 Follicle-stimulating hormone receptor mRNA in the mouse ovary during post-natal development in the normal mouse and in the adult hypogonadal (hpg) mouse: structure of alternate transcripts. Molecular and Cellular Endocrinology 101 197-201.

O'Shaughnessy PJ, Hu L \& Baker PJ 2008 Effect of germ cell depletion on levels of specific mRNA transcripts in mouse Sertoli cells and Leydig cells. Reproduction 135 839-850.

Russell LD, De Franca LR, Hess R \& Cooke P 1995 Characteristics of mitotic cells in developing and adult testes with observations on cell lineages. Tissue \& Cell 27 105-128.

Sha J, Baker P \& O'Shaughnessy PJ 1996 Both reductive forms of 17 $\beta$ hydroxysteroid dehydrigenase (types 1 and 3 ) are expressed during development in the mouse testis. Biochemical and Biophysical Research Communications 222 90-94.
Sharpe RM, Maddocks S \& Kerr JB 1990 Cell-cell interactions in the control of spermatogenesis as studied using Leydig cell destruction and testosterone replacement. American Journal of Anatomy 188 3-20.

Sheffield JW \& O'Shaughnessy PJ 1989 Effect of injection of gonadotropinreleasing hormone on testicular steroidogenesis in the hypogonadal (hpg) mouse. Journal of Reproduction and Fertility 86 609-617.

Teerds KJ 1996 Regeneration of Leydig cells after depletion by EDS: a model for postnatal Leydig cell renewal. In The Leydig Cell, pp 203-220. Eds AH Payne, MP Hardy \& LD Russell. Vienna: Cache River Press.

Teerds KJ, de Rooij DG, Rommerts FFG, van den Hurk R \& Wensing CJG 1989 Proliferation and differentiation of possible Leydig cell precursors after destruction of the existing Leydig cells with ethane dimethane sulphonate: the role of $\mathrm{LH} /$ human chorionic gonadotrophin. Journal of Endocrinology 122 689-696.

Ward CM, Barrow KM \& Stern PL 2004 Significant variations in differentiation properties between independent mouse ES cell lines cultured under defined conditions. Experimental Cell Research 293 229-238.

Yao HH, Whoriskey W \& Capel B 2002 Desert Hedgehog/Patched 1 signaling specifies fetal Leydig cell fate in testis organogenesis. Genes and Development 16 1433-1440.

Received 23 November 2007

First decision 7 January 2008

Accepted 13 February 2008 